\title{
当院における高位脛骨骨切り術の術後経過
}

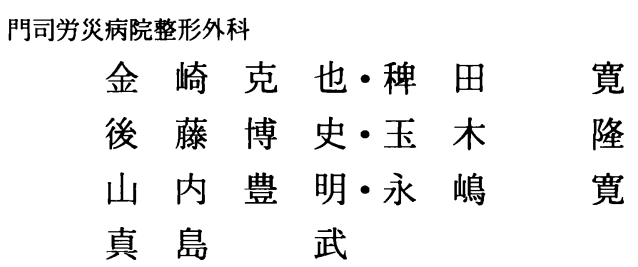

\section{A Clinical Study of Post Operative High Tibial Osteotomy for Medial Osteoarthrosis of the Knee}

by

\author{
Katsuya Kanesaki, Hiroshi Hieda, Hiroshi Goto, Takashi Tamaki, \\ Toyoaki Yamanouchi, Kan Nagashima and Takeru Mashima \\ Department of Orthopaedic Surgery, Moji Rosai Hospital
}

\begin{abstract}
We reviewed twenty-six patients who were operated on using a high tibial osteotomy due to medial osteoarthrosis of the knee. Seven cases were male and 19 female. At the time of operation, mean age was 63 years (range, 52 to 72 years), mean follow up period was 2 years and 9 months (range, 6 months to 9 years).

Evaluation was carried according to the JOA score and single standing roentgenogram of the knee.

Results were as followed;

1. 22 cases (77\%) were good results.

2. Post operative FTA which was $169 \pm 3.4$ degree.

3. Osteotomy degree was decided by Mikulicz line passed through mid portion of lateral joint line.
\end{abstract}

Key words : high tibial osteotomy（高位脛骨骨切り術), post operative follow up (術後経過), Mikulicz line（ミクリッツ線）

はじめに

内反型の变形性膝関節症はただ単に脛骨が内反して いるだけではなく, 脛骨の関節面における外側垔脱臼 を伴っている症例む多くみられる. このような症例に は外反骨切り術を行い荷重軸を内側より外側へ移動さ せる必要性がある. 現在広く行われている高位脛骨骨 切り術 (以下 HTO と略す) は Coventry 以来数々の 安定した術後成績の報告がある. 今回我々は当院で施 行した HTO の術後成績を臨床症状, FTA の変化お よび患者の満足度で検討したので報告する.

\section{症例および方法}

過去 9 年間で施行した HTO は 31 例であり，その 内術後 6 力月以上経過した 26 例を対象とした。 男 7 例女 19 例, 手術時年齢は 52 歳から 72 歳平均 63 歳, 術後経過観察期間は 6 力月から 9 年平均 2 年 9 力月で あった。

臨床症状は日本整形外科学会变形性膝関節症治療成 績判定基準（以下 JOA score と略す）を用いて評価 した. FTA の变化は非荷重時および荷重時の術前, 骨瘉合時, 調查時の下肢長尺を用いた。満足度は 5 段 
表 1 JOA score の評価 全ての項目において改善していた。

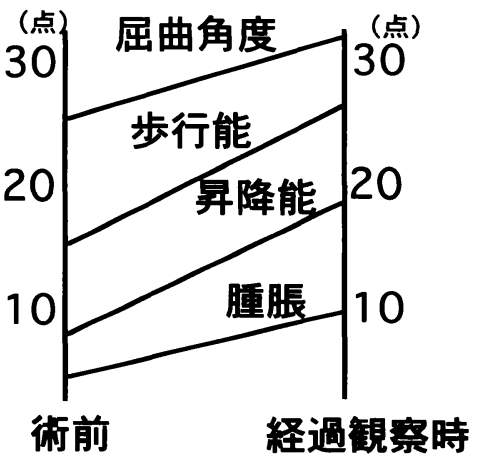

表 2 FTA の変化 有意な内反傾向はなかった。

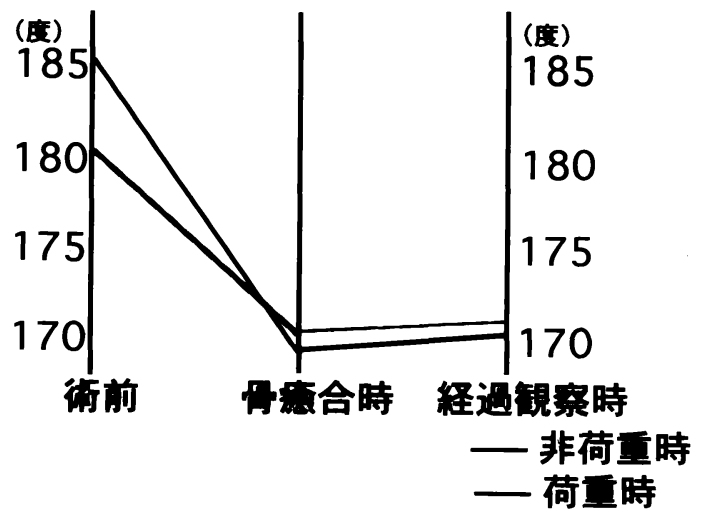

階評価でとてあよかった，よかった（人に勧める）， よかった（人に勧める程であない），わからない, ゃ らないほうがよかったとした。

\section{手 術方 法}

治療効果を上げるためには適応を慎重に検討する必 要がある. 術前には単純レ線の他に関節造影, さらに 関節鏡を行い必要であれば内側コンパートメントの abrasion を行う.すなわち外側コンパートメントの 関節軟骨に変性変化がないか, あっても寡少であるこ とが外反骨切り術の必須条件となる.

腓骨の骨切りは腓骨神経の損傷を避けるために腓骨 の中央で約 $1.5 \mathrm{~cm}$ の長さで切除する. 初期の症例で 術後に出血による外側コンパートメント症候群と思わ れる症状, 特に下腿外側から足背にかけての異常知覚
表 35 年以上経過観察例の FTA の推移 1 例のみ術後 6 年で TKA へ移行した.

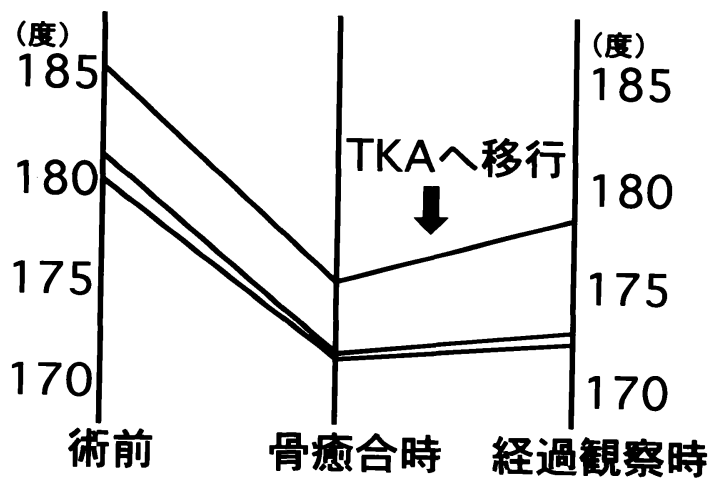

が残存している症例を経験したので，現在では筋膜縫 合はおこなっていない，脛骨の骨切りは脛骨粗面の外 側に約 $7 \mathrm{~cm}$ の皮切後, 術前に下肢長尺レ線で計画し た骨切り角度で wedge osteotomy を行う．骨切り角 は術前の立位下肢長尺の Mikukicz 線が外側関節面の 中央を通るように作図し決定している. 内固定材料は 最近では staple を用いている.

術後は 4 週間の外固定後可動域訓練を開始している. 部分荷重は術後 8 週からで自信が付き次第全荷重へ移 行している.

結果

JOA score は術前平均 55.2 点から術後平均 86 点に 改善していた. その内訳は疼痛・歩行能は 15.6 点か ら 26.2 点に, 疼痛・階段昇降能は 9.4 点から 18.7 点 に, 屈曲角度は 25.6 点から 31 点に, 腫脹は 4.2 点か ら 10 点にそれぞれ改善していた（表 1 ）.

FTA の変化は非荷重時術前平均 $180.3 \pm 2.0$ 度から 骨癒合時平均 $170.8 \pm 4.5$ 度へ，荷重時術前平均 185.8 土4.2 度から骨癒合時平均 $169.8 \pm 5.9$ 度へ変化してい た. 観察時は非荷重時 $171.5 \pm 5.9$ 度，荷重時 $170.2 \pm$ 3.6 度と骨癒合時と有意差はなかった。 また骨癒合時, 観察時とも非荷重時, 荷重時間では有意差はなかった (表 2 ).

5 年以上経過観察可能であった症例は 3 例あり, FTA の推移は表 3 のごとくである. このうち 2 例の FTA は骨癒合時 172 度, 173 度であり経過観察時は 有意な内反はなくそれぞれ 173 度, 174 度で満足度は よかった. しかし 1 例は手術時 70 歳の女性で, 術前 

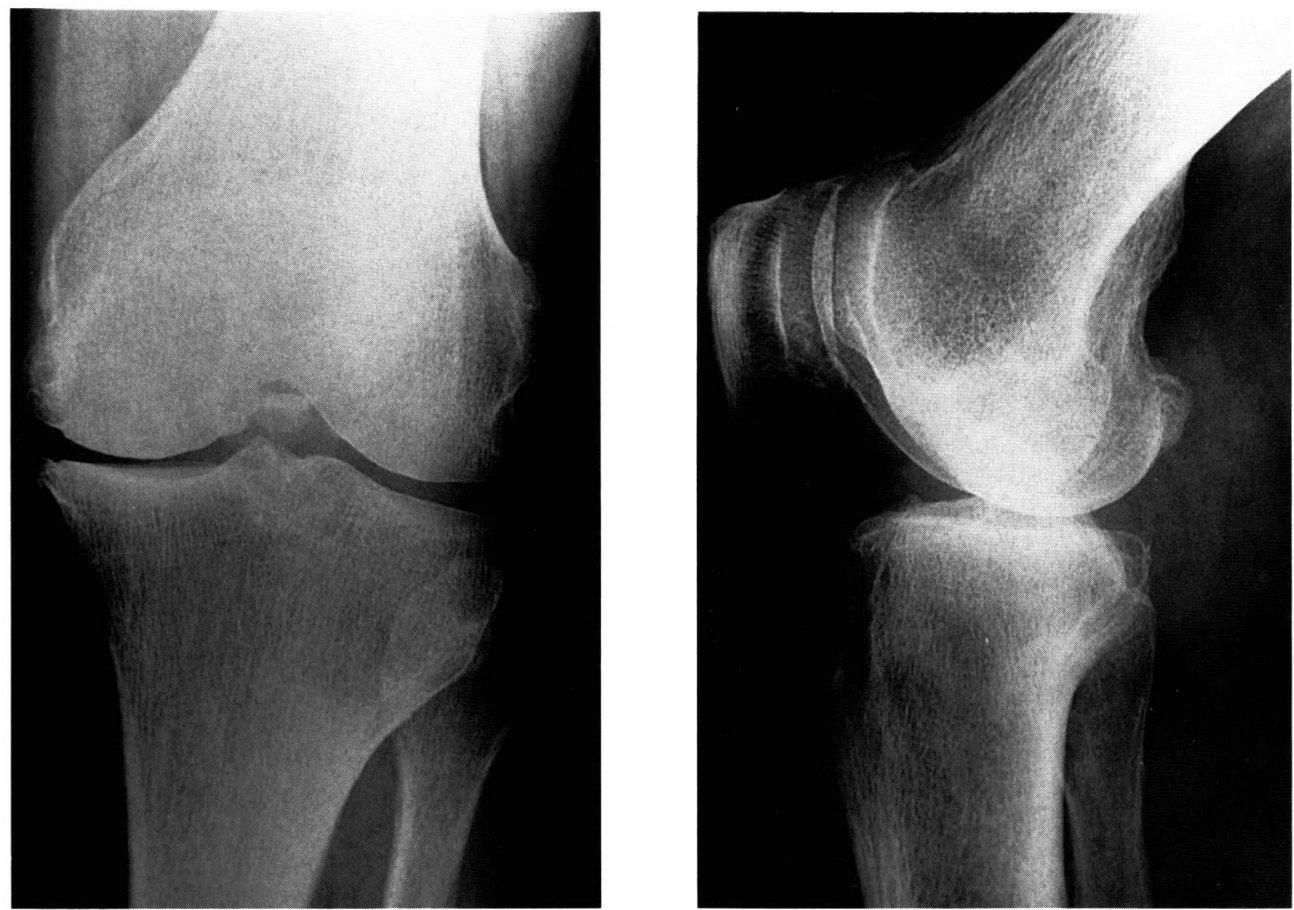

図 1 術前単純レ線

顆間顆部に関節鼠あり

185 度, 骨癒合時 175 度, 経過観察時 178 度と有意な 内反はないものの, 術後臨床経過は 6 力月まで症状軽 快傾向にあったが，それ以後は膝内側の疼痛が増強し 術後 6 年で TKA へ移行した.

5 段階評価の満足度はとてもよかったと答えた人は いなかったが，よかった（人に勧める）と答えた人は 13 例 (50\%)，よかった（人に勧める程でもない）は 7 例 (27\%) と両群で全体の $77 \%$ を占めていた。わ からないは5 例 (19.2\%)，やらないほうがよかった は1例 $(3.8 \%)$ であった。この 1 例は前述の TKA 移行例であった。

また満足度と観察時 FTA の関係は, よかったと答 えた 20 例の平均は $169.7 \pm 3.4$ 度，わからない以下の 6 例の平均は $174.4 \pm 5.9$ 度であり $0.01 \%$ の危険率で有 意差があった.

\section{症例}

63 歳女性. 数年来左膝関節痛あり。突然の膝伸展 傷害にて来院. 来院時膝伸展 -30 度, 屈曲 90 度であっ
た. 単純レ線では関節鼠によるロッキングと思われた (図 1 ). 局所麻酔剂 $30 \mathrm{ml}$ を関節内注入後ロッキング は解消された。術前の非荷重時 FTA は 180 度, 荷重 時FTA は 185 度であった（図 2 ). 術後 2 年後の経 過観察時, 非荷重時 FTA は 167 度, 荷重時 FTA は 164 度であった（図 3 )。階段昇降時に手すりを使わ ないと痛みが残る程度で満足度はよかった（人に勧め る)であった.

$$
\text { 考 察 }
$$

内側型変形性膝関節症は内反ストレスが持続し, 内 側関節面に変性変化が起きることは周知の事実である. 当然外側関節面は hypopressure の状態にあるがその ほとんどは変性の状態ではなく, 骨切り術により荷重 線を内側から外側へ移すことによって治療効果が期待 できる.

HTO はすでに確立された術式であると思われるが, その骨切り角の決定方法も術前の立位または仰臥位の よ゙ちらで計測するか，また骨切り方法にあ単なる 

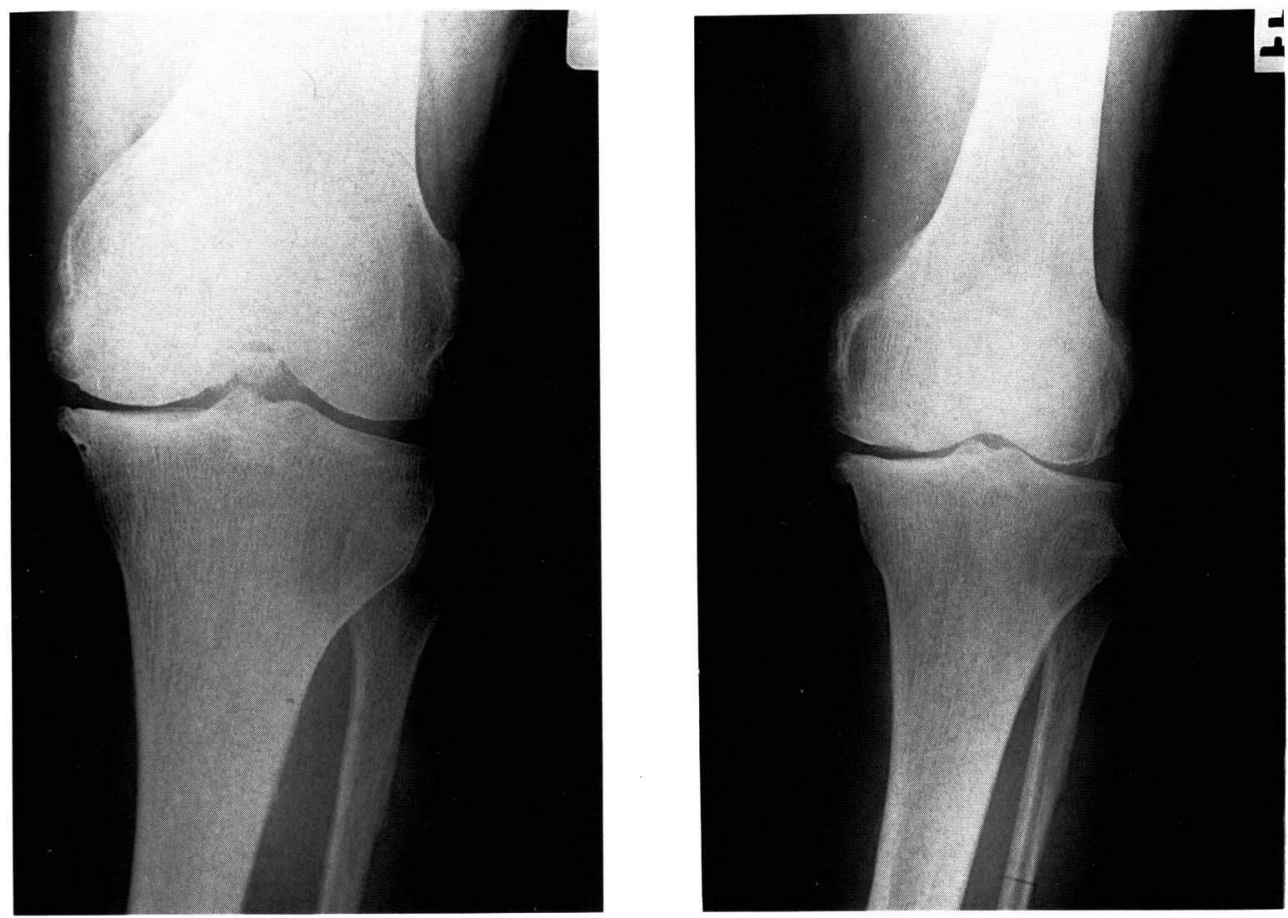

図 2 術前FTA 評価

非荷重時 180 度, 荷重時 185 度

wedge osteotomy か dome 型, inter locking wedge など種々な報告がある.

緒方ら ${ }^{2)}$ は術前仰臥位の関節裂隙角度が術後立位の あのと近似するために骨切り角度は仰卧位で決定する としている. また骨切り術の方法も通常の wedge osteotomy の際に回旋を加えたり脛骨粗面を前方へ 引き出すと骨切り部の接触面積が減少し, 安定性も低 下するので術後偽関節の可能性が高くなるとし inter locking wedge osteotomy を勧めている.

また Hernigouら ${ }^{1)}$ は lateral joint laxity の大きい 症例や内反の強い症例は過矯正を防ぐために仰臥位の レ線で矯正角度を決めるとしている.

今回の我々の術後経過観察の結果では, 骨癒合時に 比して経過観察時に有意な内反変形を来している症例 はなかった。 しかし内反矯正が不足し満足度が低く $\mathrm{TKA}$ へ移行した症例は 6 年間で 3 度の内反が起り, FTA は 178 度であった。観察時 Mikulicz 線は内側 関節面を通過していた。

以上のことより内側型変形性膝関節症に対する
HTO の矯正角度不足は致命的であり, かえって過矯 正の方が良好な成績を残すと思われた，我々は経験な いが文献的には過矯正例のなかには外側型変形性膝関 節症に進行する危険性も秘めており術後長期経過でみ ると成績は落ちてくると思われる，したがって再内反 を来さず，かつ外側型变形性膝関節症にも移行せず長 期にわたり安定した成績を得る至適矯正角度は Mikulicz 線が外側関節面中央を通過する角度, FTA では 170 度弱を目標にすべきである.

$$
\text { ま と め }
$$

1.内側型変形性膝関節症に対する HTO の術後経 過を検討した。

2. 20 例 $(77 \%)$ の満足度は高かった。

3. 満足度の高かった症例の観察時 FTA は 169.7 土3.4 度であった。

4. 至適矯正角度は Mikulicz 線が外側関節面中央 を通過する角度である。 

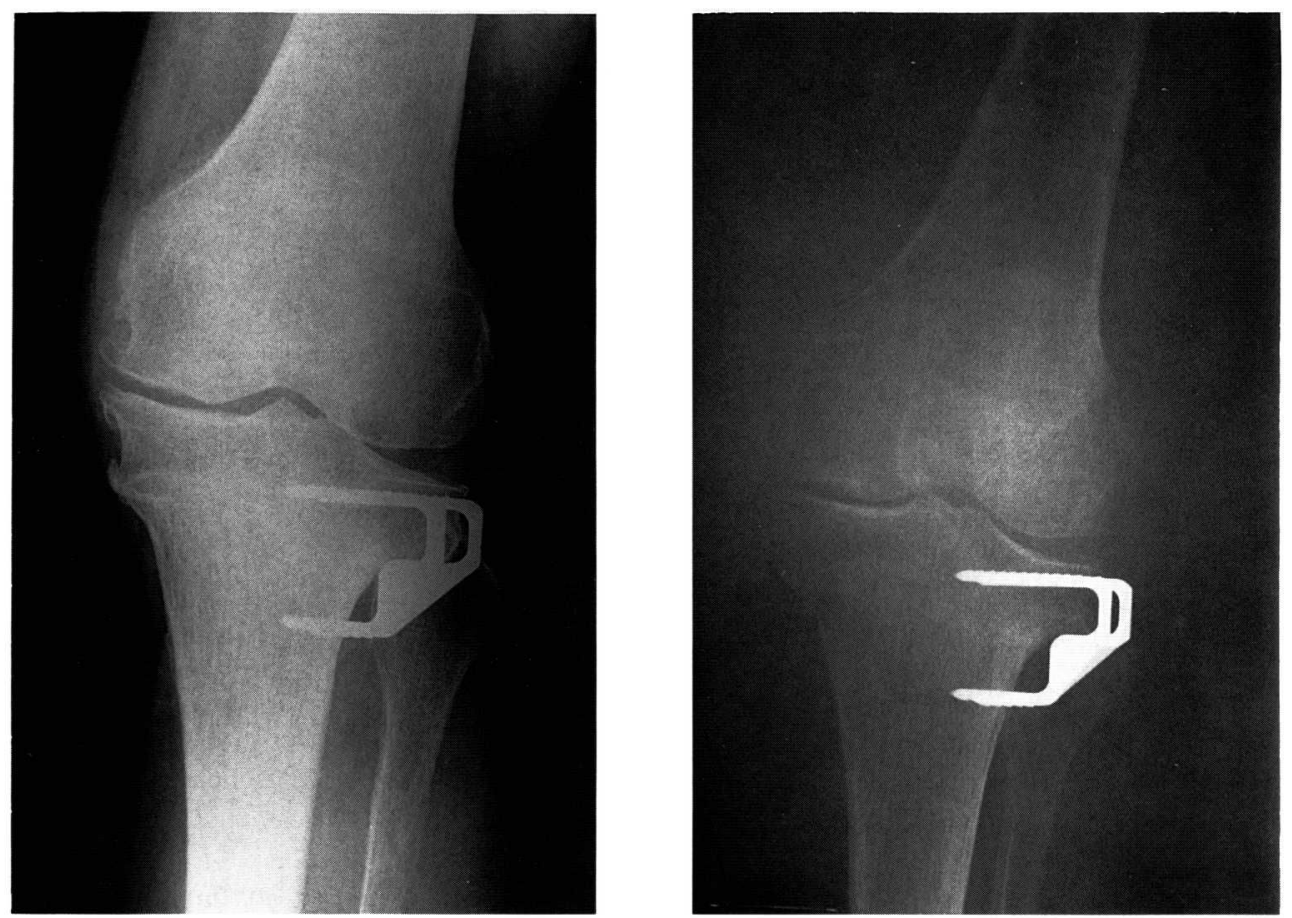

図 3 観察時 FTA 評価

非荷重時 167 度, 荷重時 164 度

\section{参考 文 献}

1) Hernigou, P. H. et al. : Proximal tibial osteotomy for osteoarthritis with varus deformity. J. B. J. S. 69 - A :
332-345, 1987.

2）緒方公介ほか：高位脛骨骨切り術における inter locking wedge osteotomyについて. 臨床整形外科, 18: 159-164, 1983. 